\title{
Isolation and Characterization of Urease-Producing Soil Bacteria
}

\author{
Eshetu Mekonnen $\mathbb{D}^{1},{ }^{1}$ Ameha Kebede, ${ }^{2}$ Asefa Nigussie, ${ }^{3}$ Gessese Kebede, ${ }^{3}$ \\ and Mesfin Tafesse ${ }^{3}$ \\ ${ }^{1}$ Dire Dawa University, College of Natural and Computational Sciences, Department of Biology, Dire Dawa, Ethiopia \\ ${ }^{2}$ Haramaya University, College of Natural and Computational Sciences, School of Biology and Biotechnology, \\ Haramaya, Ethiopia \\ ${ }^{3}$ Addis Ababa Science and Technology University, Department of Biotechnology, Addis Ababa, Ethiopia \\ Correspondence should be addressed to Eshetu Mekonnen; eshetumicro@gmail.com
}

Received 31 July 2020; Revised 11 March 2021; Accepted 5 July 2021; Published 10 July 2021

Academic Editor: Joseph Falkinham

Copyright (c) 2021 Eshetu Mekonnen et al. This is an open access article distributed under the Creative Commons Attribution License, which permits unrestricted use, distribution, and reproduction in any medium, provided the original work is properly cited.

\begin{abstract}
Urease is an enzyme produced by ureolytic microorganisms which hydrolyzes urea into ammonia and carbon dioxide. Microbial urease has wide applications in biotechnology, agriculture, medicine, construction, and geotechnical engineering. Ureaseproducing microbes can be isolated from different ecosystems such as soil, oceans, and various geological formations. The aim of this study was to isolate and characterize rapid urease-producing bacteria from Ethiopian soils. Using qualitative urease activity assay, twenty urease-producing bacterial isolates were screened and selected. Among these, three expressed urease at high rates as determined by a conductivity assay. The isolates were further characterized with respect to their biochemical, morphological, molecular, and exoenzyme profile characteristics. The active urease-producing bacterial isolates were found to be nonhalophilic to slightly halophilic neutrophiles and aerobic mesophiles with a range of tolerance towards $\mathrm{pH}(4.0-10.0), \mathrm{NaCl}(0.25-5 \%)$, and temperature $\left(20-40^{\circ} \mathrm{C}\right)$. According to the API ZYM assays, all three isolates were positive for alkaline phosphatase, leucine aryl amidase, acid phosphatase, and naphthol_AS_BI_phosphohydrolase. The closest described relatives of the selected three isolates (Isolate_3, Isolate_7, and Isolate_11) were Bacillus paramycoides, Citrobacter sedlakii, and Enterobacter bugandensis with 16S rRNA gene sequence identity of 99.0, 99.2, and 98.9\%, respectively. From the study, it was concluded that the three strains appear to have a relatively higher potential for urease production and be able to grow under a wider range of growth conditions.
\end{abstract}

\section{Introduction}

Urease is an enzyme that catalyzes the hydrolysis of urea by all plants and many algae, fungi, and bacteria [1]. As a consequence, urease activity (urea amidohydrolase: EC 3.5.1.5) is widely distributed in soil $[2,3]$. Microbial urease has also been studied in clinical samples as it is related to the virulence of pathogenic microorganisms [4], contributing to urinary stones, pyelonephritis, and gastric ulceration $[5,6]$. Ureases were immobilized and used as a biosensor in the construction of a flow cell with the incorporation of a urease-modified device for the continuous measurement of urea in flowing systems [7]. They were also used along with urea fertilizer to ease the hydrolysis of ammonium into the soil [8]. However, in the last two decades, the use of microbial urease has switched from clinical relevance to geotechnical engineering and applied biotechnology [9], because of the abilities of microorganisms to induce calcite precipitation, a common natural soil cementing agent, in the presence of urea and calcium ions [10, 11].

Several aerobic bacteria genera (i.e., Proteus, Morganella, Serratia, Pseudomonas, Clostridium, Fusobacterium, Ureaplasma, Providencia, Sarcina, Lactobacillus, Streptococcus, and Enterobacter) are known to produce the enzyme urease and are able to degrade urea in the soil under aerobic conditions $[1,12]$. Urease turns the uncharged urea molecule into two charged ions: ammonium $\left(\mathrm{NH}^{4+}\right.$, positively charged) and carbonate $\left(\mathrm{CO}_{3}^{2-}\right.$, negatively charged) $[4,12]$. As a result, the ammonium $\left(\mathrm{NH}^{4+}\right)$ released from urea hydrolysis results in local $\mathrm{pH}$ rise and commences the precipitation of calcium carbonate [13]. 
Microbial urease can exist in two possible states in soil. It occurs either intracellularly, associated directly with ureolytic microorganisms, or extracellularly, after being released from cells $[14,15]$. Urease-producing bacteria are of particular interest for the production of complex bioenzymes and are known to produce other soil enzymes [16] that lead to the stabilization of expansive clays [17] through cation exchange and flocculation of the clay minerals $[18,19]$.

Reference [20] estimated that the microorganisms capable of hydrolyzing urea comprised between 17 and $30 \%$ of the aerophilic, microaerophilic, and anaerobic microorganisms isolated from their soil samples. Their ability to produce urease can be exploited to enrich and isolate such bacteria from the environment for future applications [21]. While the occurrence of these bacteria and their characteristics have been explored in some regions and soil types $[1,12,21,22]$ and other novel bacterial strains isolated from Ethiopian sediments and soils [23, 24], this study is the first report on the characterization of ureolytic bacteria from Ethiopian soil. This study aimed to isolate and characterize rapid ureaseproducing bacteria from Ethiopian soils. Thus, ureolytic bacteria were isolated from soils and were identified based on their urease activity and 16S rRNA gene sequence analysis. Selected rapid urease producer strains were further characterized by biochemical, morphological, molecular, and exoenzyme profile characteristics.

\section{Materials and Methods}

2.1. Soil Sampling. Soil samples were collected from different types of ecosystems including a urea dumping site, stable soil structures such as termite casts, and rift valley soda lakeshores of Ethiopia. The samples were collected in summer 2017 from Tulu Bolo Fertilizer Factory $(\mathrm{pH}=8.15$, soil temperature $=28^{\circ} \mathrm{C}, 8.6633^{\circ} \mathrm{N}, 38.2164^{\circ} \mathrm{E}$, and at an elevation of 2193 meters above sea level); shore soil of Lake Abijata $\left(\mathrm{pH}=10.5\right.$, soil temperature $=32^{\circ} \mathrm{C}, 7.6167^{\circ} \mathrm{N}, 38.6000^{\circ} \mathrm{E}$, and at an elevation of 1573 meters above sea level); shore soil of lake Chitu $\left(\mathrm{pH}=11.5\right.$, soil temperature $=30^{\circ} \mathrm{C}$, $7.403599^{\circ} \mathrm{N}, 38.423527^{\circ} \mathrm{E}$, and at an elevation of 1539 meters above sea level); a termite mound in the Wonji area $\left(\mathrm{pH}=7.56, \quad\right.$ soil temperature $=33^{\circ} \mathrm{C}, \quad 8.450919^{\circ} \mathrm{N}$, $39.278972^{\circ} \mathrm{E}$, and at an elevation of 1618.28 meters above sea level); termite mounds near the town of Yabello $(\mathrm{pH}=7.9$, soil temperature $=31^{\circ} \mathrm{C}, 4.889622^{\circ} \mathrm{N}, 38.084775^{\circ} \mathrm{E}$, and at an elevation of 1,857 meters above sea level); and a termite mound in West Wollega $\left(\mathrm{pH}=6.7\right.$, soil temperature $=30^{\circ} \mathrm{C}$, $9.487993^{\circ} \mathrm{N}, 35.526785^{\circ} \mathrm{E}$, and at an elevation of 1821 meters above sea level) [25].

The soil samples consisted of homogenized composite samples taken from multiple sample units as described in [26]. The soil samples were collected from the upper $10 \mathrm{~cm}$ of the topsoil, sampling was done using a sterile spatula, and the samples were kept in sterile polyethylene bags [27]. The samples were immediately stored in an ice-box at $4^{\circ} \mathrm{C}$ and transported to the laboratory at Addis Ababa Science and Technology University.
2.2. Enrichment and Screening of Ureolytic Bacterial Isolates. To enrich urease-producing bacteria from soil samples, $1 \mathrm{~g}$ of each soil sample was inoculated into $100 \mathrm{~mL}$ of urea broth medium (Sigma-Aldrich) consisting of $1.00 \mathrm{mg} / \mathrm{L}$ peptone, $1.000 \mathrm{mg} / \mathrm{L}$ dextrose, $5.00 \mathrm{mg} / \mathrm{L}$ sodium chloride, $1.2 \mathrm{mg} / \mathrm{L}$ disodium phosphate, $0.8 \mathrm{mg} / \mathrm{L}$ monopotassium phosphate, $0.012 \mathrm{mg} / \mathrm{L}$ of phenol red, and $6 \%(\mathrm{w} / \mathrm{w})$ urea (HiMedia, sterile filtered $0.45 \mu \mathrm{m}$, added after autoclaving) (in $250 \mathrm{~mL}$ shake flasks) and incubated under aerobic batch conditions at $30^{\circ} \mathrm{C}$ for $120 \mathrm{~h}$ under shaking condition at $130 \mathrm{rpm} \mathrm{[21].}$ For subsequent enrichment, 20\% (v/v) of the culture samples were intermittently transferred (up to four times) into a fresh medium [28]. For bacterial isolation, an aliquot of $1 \mathrm{~mL}$ was serially diluted and from the last enrichment, $0.1 \mathrm{~mL}$ of the sample was inoculated onto urea agar plates and then spread using a sterilized L-shaped spreader until the fluid was evenly distributed [21]. The plates were then incubated under aerobic conditions at $30^{\circ} \mathrm{C}$ for $24 \mathrm{~h}$. Colonies showing urea hydrolyzing potential were purified by subsequent culturing and plating until single bacterial colonies were obtained. Urease production was tested through visual observation of color changes. Thus, isolates with positive ureolytic potential turned the urea agar medium from pale yellow to a pink-red color [29]. From a total of 153 collected colonies, 20 potential urease-producing isolates were selected for further studies.

2.3. Quantitative Urease Activity Analysis. For direct assays of urease activity, $1.0 \mathrm{~mL}$ of a $24 \mathrm{~h}$ old culture was inoculated into bottles containing $9.0 \mathrm{~mL}$ of $1.11 \mathrm{M}$ urea solution and monitored for $5 \mathrm{~min}$ at $25 \pm 2^{\circ} \mathrm{C}$. The respective conductivity values were measured and recorded by immersing the probe of the conductivity meter (EC800 Laboratory Benchtop Conductivity Meter, APERA) into the bacterial-urea solution [30]. At the end of the assay, a graph was plotted using conductivity values $(\mathrm{ms} / \mathrm{cm})$ against time $(\mathrm{min})$. The rate of conductivity change $(\mathrm{ms} / \mathrm{cm} / \mathrm{min})$ was acquired from the slope of the plotted graph, which was then multiplied by the dilution factor. This was taken as the ratio of the stock bacteria culture to the sampling bacteria culture before inoculation into the urea solution. The specific urease activity (mM urea hydrolysed/min/OD) was derived by dividing the urease activity ( $\mathrm{mM}$ urea hydrolysed/min) by the bacterial biomass $\mathrm{OD}_{600}$ [31]. The OD was measured using a spectrophotometer (GENESYS ${ }^{\mathrm{TM}} 20$, Thermo Fisher Scientific) at a wavelength of $600 \mathrm{~nm}$ :

specific urease activity

(mM urea hydrolysed. min-1.OD-1)

$$
=\frac{\text { urease activity }(\mathrm{mM} \text { urea hydrolysed. } \mathrm{min}-1)}{\text { biomass (OD600) }} \text {. }
$$

2.4. Colony and Cell Morphology. Morphological characterization such as colony and cell morphology; Gram, India ink, and malachite green stain reaction; and motility tests were performed by standard methods [32]. Microscopic observations were performed under a light microscope 
(Zeiss Axio Lab.A1, Carl Zeiss, with AxioCam Mrm camera) [33].

2.5. 16S RNA Gene Amplification. Genomic DNA of each bacterial isolate was extracted using the freeze and thaw protocol and used as a template in a PCR using the primers 8f ( $5^{\prime}$-AGAGTTTGATCCTGGCTCAG-3') and 1492r ( $5^{\prime}$ GGTTACCTTGTTACGACTT- $3^{\prime}$ ) as previously described in [34]. Colonies of overnight grown isolates were picked using a sterilized pipette tip, mixed with $10 \mu \mathrm{L}$ of PCR grade water in a sterile PCR tube, and placed in a thermocycler with freeze-thaw cycles consisting of three stages with $96^{\circ} \mathrm{C}$ for $15 \mathrm{~min}, 90 \mathrm{sec}$, and $60 \mathrm{sec}$ followed by $15^{\circ} \mathrm{C}$ for $90 \mathrm{sec}$ at each stage. One microliter of the lysed cells was transferred into $20 \mu \mathrm{L}$ of PCR master mix. The master mix consists of $16.2 \mu \mathrm{L}$ PCR grade water, $2 \mu \mathrm{L}$ of $10 \mathrm{x}$ PCR buffer (Life Technologies), $0.4 \mu \mathrm{L}$ of $10 \mathrm{mM}$ DNTP mix (Life Technologies), $0.4 \mu \mathrm{L}$ of $20 \mathrm{mg} / \mathrm{mL} \mathrm{BSA}, 0.8 \mu \mathrm{L}$ of $25 \mathrm{mM} \mathrm{MgCl}_{2}$, $0.08 \mu \mathrm{L}$ of $50 \mu \mathrm{M}$ of each primer $8 \mathrm{f}, 1492 \mathrm{r}$, and dream taqPolymerase (Life Technologies). DNA amplification was performed using a Thermocycler (Verti Cycler, Applied Biosystems).

2.6. Nucleotide Sequencing and Analysis. Sequencing was done using the Illumina sequencing facility and the raw DNA chromatogram sequences were viewed and edited using the BioEdit Programme [35] and stored in FASTA format. The forward and reverse sequencing products were assembled using MEGA X after removing poor-quality sequences from the $3^{\prime}$ and $5^{\prime}$ sequence ends. The sequences were blasted against existing sequences in the National Centre for Biotechnological Information (NCBI) database using the Basic Local Alignment Search Tool (BLAST) nucleotide collection database program to search for the closest best match sequence [36].

2.7. Optimization of Growth Conditions. The one-factor-ata-time (OVAT) technique was employed to study the effects of culture conditions affecting bacterial growth such as incubation temperature $\left(4-45^{\circ} \mathrm{C}\right)$, initial medium $\mathrm{pH}$ (4.0-10.0), and $\mathrm{NaCl}$ concentrations (0-20\%) in triplicate under oxic conditions. The bacterial cultures were grown in a urea broth base medium $(24.0 \mathrm{~g} / \mathrm{L}$, HiMedia Laboratories Pvt. Ltd.) and supplemented with filtered urea $(5 \% \mathrm{w} / \mathrm{v}$, Thermo Fisher Scientific) using a $0.45 \mu \mathrm{m}$ sterile syringe filter [3].

2.7.1. Testing for Optimum $p H$. To test the range and optimum $\mathrm{pH}$, a medium was prepared at different $\mathrm{pH}$ $(\mathrm{pH}=3-10)$ at $0.5 \mathrm{pH}$ intervals. The $\mathrm{pH}$ within a desired range $10 \mathrm{mM}$ of the following buffers was maintained. MES buffer (2-( $N$-morpholino)ethanesulfonic acid) was used for the $\mathrm{pH}$ range from 3.0 to 6.7; HEPES buffer (4-(2-hydroxyethyl)-1piperazineethanesulfonic acid) for the $\mathrm{pH}$ range from 6.8 to 8.2, HEPPS buffer (3-[4-(2-Hydroxyethyl)piperazin-1-yl] propane-1-sulfonic acid) for the range from 7.3 to 8.7 ; and
CHES buffer (N-Cyclohexyl-2-aminoethanesulfonic acid) for the $\mathrm{pH}$ range from 8.6 to 10 [37].

For each $\mathrm{pH}$ step, $4.5 \mathrm{~mL}$ of medium was added to test tubes (triplicate) and inoculated with $0.5 \mathrm{~mL}$ of fresh culture. Samples were incubated at $33^{\circ} \mathrm{C}$ under oxic condition and $\mathrm{OD}_{600}$ was recorded at intervals of $0 \mathrm{~h}$ to $24 \mathrm{~h}$. The sterile medium was used as blank. Finally, growth curves were plotted as LogOD versus time for each $\mathrm{pH}$, and the optimum was determined. Optimal growth was defined as $\geq 75 \%$ of the highest growth rate achieved [38].

2.7.2. Testing for Optimum Temperature. To test the range and optima temperature, media was prepared at the optimum $\mathrm{pH}$ as indicated above. For each temperature, $4.5 \mathrm{~mL}$ of medium was added to test tubes (triplicate) and inoculated with $0.5 \mathrm{~mL}$ of fresh culture. The tubes were incubated under the oxic condition at temperatures between 5 and $45^{\circ} \mathrm{C}$ at intervals of $5^{\circ} \mathrm{C} . \mathrm{OD}_{600}$ was recorded at intervals of $1 \mathrm{~h}$ for $24 \mathrm{~h}$. The uninoculated medium was used as blank. Finally, the growth curve was plotted as time versus log OD for each temperature and the optimum was determined [39].

2.7.3. Testing for Optimum Salinity. Media were prepared with the optimum $\mathrm{pH}$ and for each $\mathrm{NaCl}$ concentration to be tested $(0,0.25,0.5,1.0,2.0,3.0,4.0$, and $5.0 \mathrm{~g} / \mathrm{L}$ final concentration $(\mathrm{w} / \mathrm{v}))$; then, $4.5 \mathrm{~mL}$ of medium was added to test tubes (triplicate) and inoculated with $0.5 \mathrm{~mL}$ of fresh culture. Tubes were incubated and recorded as indicated above.

2.8. Exoenzyme Analysis. Indole formation, aesculin degradation, urease activity, and further exoenzyme activities were determined by using the API ZYM and API20NE test systems (bioMerieux) following the instructions of the manufacturer. API ZYM is a semiquantitative micromethod designed for the research of enzymatic activities [40]. It allows the systematic and rapid study of 19 enzymatic reactions using very small sample quantities [41]. After inoculation, the reaction mixture was incubated for $4-4.5 \mathrm{~h}$ at $35^{\circ} \mathrm{C}$ (optimum temperature) [42]; then, the data was recorded and interpreted.

2.9. Phylogenetic Analysis. A phylogenetic tree based on $16 \mathrm{~S}$ rRNA gene sequences was reconstructed using MEGA version 10.0 [43]. Prior to phylogenetic analysis, primer sequences at both ends were removed and the gaps were adjusted to improve the alignment. Nucleotide sequence alignments were inspected visually to identify positions of uncertain alignments to be corrected or omitted for further analysis [44]. Multiple sequence alignments were obtained using the Clustal-W alignment tool from the MEGA-X software with distance options according to the Kimura twoparameter model and clustering with the maximum likelihood statistical method [44]. Bootstrap analysis based on 1000 replications was used to estimate the confidence level of the tree topologies [43]. 


\section{Results}

\subsection{Isolation, Urease Activity, Phylogenetic Analysis, and Morphological Features of the Isolated Bacteria}

3.1.1. Isolation and $16 S$ RNA Gene Similarity. Numerous active urease-producing bacterial cultures were enriched and a total of 153 ureolytic pure bacterial colonies were collected after a consecutive restreaking [45]. Twenty strains with high urease activity were identified based on the rapid development of the pink color of the urea agar plates within $24 \mathrm{~h}$ of incubation [12] and selected for further investigation. The selected 20 isolates were subjected to partial 16S rRNA gene sequencing [46] at the Leibniz-Institute DSMZ-German Collection of Microorganisms and Cell Cultures. The BLAST results of the sequences searched against the GenBank database using the BLASTN program [47] are summarized in Table 1.

The phylogenetic definition of a species generally would include strains with approximately $70 \%$ or greater DNADNA relatedness and with $5^{\circ} \mathrm{C}$ or less $\Delta \mathrm{T}_{\mathrm{m}}$ [48]. A $16 \mathrm{~S}$ rRNA gene sequence similarity of $98.6 \%$ [49] was generally used as a threshold value for species definition in prokaryotes taxonomy. Accordingly, in this study, the sequence analysis showed that $3(15 \%), 3(15 \%)$, and $14(70 \%)$ of the isolates belong to the genera Bacillus, Citrobacter, and Enterobacter, respectively (Table 1 ).

3.1.2. Specific Urease Activity Testing. The specific urease activity of each bacterial isolate was measured and the analysis is presented in Figure 1. Based on the quantitative analysis, Isolate_3, Isolate_7, and Isolate_11 showed clearly higher specific urease activity values of $3.88,3.18$, and $3.05 \mathrm{mM}$ urea hydrolysed/min/OD, respectively $(p<0.001)$, and were selected for further analysis. Only these three isolates with higher specific urease activity were selected for analysis due to the limited budget and time during the study time.

3.1.3. Phylogenetic Analysis of the Selected Isolates. The phylogeny of the isolates was analyzed using the maximum likelihood method and the Kimura 2-parameter model and included bootstrap analysis based on 1000 replications [43] to estimate the confidence level of the tree topology. The analysis revealed that Isolate_3 was affiliated with the genus Bacillus (Figure 2). The highest 16S rRNA gene sequence identity for Isolate_3 (MW723439) was 98.9\% and was determined for Bacillus paramycoides MCCC $1 \mathrm{~A} 04098^{\mathrm{T}}$. The analysis placed Isolate_7 (MW722959) in the vicinity of Citrobacter sedlakii $\mathrm{I}-75^{\mathrm{T}}$ and within the same group $(99.2 \%$ $16 \mathrm{~S}$ rRNA sequence identity). The phylogenetic analysis also showed that Isolate_7 is more closely related to Isolate_11 than Isolate_3. Isolate_11 (MW722969) was placed in the neighborhood of Enterobacter bugandensis $247 \mathrm{BMC}^{\mathrm{T}}$ which had a $16 \mathrm{~S}$ rRNA gene sequence identity of $99.0 \%$ to this type of strain.

3.1.4. Cellular and Colony Features of the Selected Isolates. Microscopic examination of Isolate_11 showed that cells stained Gram-negative and are single coccobacilli to rod-shaped with an average length of $0.6-1.8 \mu \mathrm{m}$ (Figure 3(c)). The cells were motile when they were observed in a wet mount with phase-contrast microscopy and by using semisolid agar stabs (agar, $2 \mathrm{mg} / \mathrm{L}$ ) [50]. Capsules and endospores were not observed after staining with India ink and malachite green, respectively. After incubation at $35^{\circ} \mathrm{C}$ for $18 \mathrm{~h}$ on a nutrient agar medium, the colonies had an average size of $2 \mathrm{~mm}$ in diameter and were whitish, smooth, shiny, circular, and convex with entire margins. Colony and microscopic features of Isolate_11 were similar to the recently described strain of Enterobacter bugandensis EB- $247^{\mathrm{T}}$ [51]. Cells of Isolate_7 stained Gram-negative and were coccobacilli to roads with an average length of $1.6 \mu \mathrm{m}$, Gram-negative, nonspore forming, and noncapsulated and occur as single cells or in short chains (Figure 3(b)). After incubation at $35^{\circ} \mathrm{C}$ for $18 \mathrm{~h}$ on nutrient agar plates, colonies were whitish to gray, convex, and circular with an average size of $2.5 \mathrm{~mm}$. These features were similar to the pathogenic Citrobacter sedlakii isolated from infant brain samples and grown on sheep blood agar plates [52].

Cells of Isolate_3 were long rods, with an average length of $1.5-4.5 \mu \mathrm{m}$ and formed highly refractile endospores (Figure 3(a)). Consistent with all other characterized members of the genus Bacillus, the cells of Isolate_3 stained Gram-positive [53]. Staining with India ink demonstrated the presence of capsules. Colonies of Isolate_3 were whitish, rough, circular, and nontranslucent and had a rough surface and entire margins, with $1.5-3.5 \mathrm{~mm}$ in diameter after incubation at $35^{\circ} \mathrm{C}$ for $24 \mathrm{~h}$ on nutrient agar plates.

3.2. Optimum and Range of Growth for $p H$, Temperature, and Salinity. The $\mathrm{pH}$ tolerance analysis showed that Isolate_11 was able to grow in a wider range of $\mathrm{pH}(\mathrm{pH} 4.0-10.0)$. The optimum growth defined as $\geq 75 \%$ of the highest growth rate achieved [39] was recorded at $\mathrm{pH}=5.5-8.0$. The highest rate of growth $(100 \%)$ was recorded at $\mathrm{pH}=7.0$ $(p<0.05)$ and the lowest rate was at $\mathrm{pH}=10.0$. Isolate_7 was able to grow between $\mathrm{pH}=5.5$ and $\mathrm{pH}=9.5$ and optimum growth was recorded between $\mathrm{pH}=6.5$ and $\mathrm{pH}=8.0$. The highest rate of growth $(100 \%)$ was observed at $\mathrm{pH}=8.0$ and it was unable to grow at lower $\mathrm{pH}=4.0$ and higher $\mathrm{pH}=10.0$. Growth was observed for Isolate_3 between $\mathrm{pH}$ of 6.5 and $\mathrm{pH}$ of 9.5 ; optimal growth $(\geq 75 \%)$ was recorded between $\mathrm{pH}$ of 7.0 and $\mathrm{pH}$ of $8.0(p<0.05)$; and the highest rate of growth $(100 \%)$ was recorded at $\mathrm{pH}=7.4$. Isolate_3 was unable to grow or showed limited growth between $\mathrm{pH}=2.8$ and $\mathrm{pH}=5.0$ (Figure 4).

The analysis of the OD values after $24 \mathrm{~h}$ of incubation at different temperatures showed that Isolate_11 could grow between $20^{\circ} \mathrm{C}$ and $40^{\circ} \mathrm{C}$ with both optimum growth $(\geq 75 \%$ of the highest growth rate) and maximum growth rate $(100 \%)$ at $35^{\circ} \mathrm{C}(p<0.05)$. It was unable to grow at a temperature range of $4-15^{\circ} \mathrm{C}$. Similarly, Isolate_7 was able to grow between $20^{\circ} \mathrm{C}$ and $40^{\circ} \mathrm{C}$ (optimum at $25^{\circ} \mathrm{C}-40^{\circ} \mathrm{C}$ ), with the highest rate of growth $(100 \%)$ at $30^{\circ} \mathrm{C}$ and $35^{\circ} \mathrm{C}$ $(p<0.05)$. It showed no or very slow growth rate between 
TABLE 1: 16S rRNA genes sequence similarity with the closest strains of the isolates.

\begin{tabular}{|c|c|c|c|}
\hline Code & Closest strain & $\%$ & Origin \\
\hline Isolate_1 & Bacillus paramycoides MCCC $1 \mathrm{~A} 04098^{\mathrm{T}}$ & 99.6 & Tulubolo \\
\hline Isolate_2 & Enterobacter tabaci YIM Hb-3 $3^{\mathrm{T}}$ & 97.1 & Lake Chitu \\
\hline Isolate_3 (MW723439) & Bacillus paramycoides MCCC $1 \mathrm{~A} 04098^{\mathrm{T}}$ & 98.9 & West Wellega \\
\hline Isolate_4 & Enterobacter tabaci YIM Hb-3 ${ }^{\mathrm{T}}$ & 97.9 & Lake Chitu \\
\hline Isolate_5 & Enterobacter asburiae JCM $6051^{\mathrm{T}}$ & 99.0 & Wonji \\
\hline Isolate_6 & Enterobacter tabaci YIM Hb-3 ${ }^{\mathrm{T}}$ & 98.9 & Lake Chitu \\
\hline Isolate_7 (MW722959) & Citrobacter sedlakii $\mathrm{I}-25^{\mathrm{T}}$ & 99.8 & Wonji \\
\hline Isolate_8 & Citrobacter sedlakii $\mathrm{I}-25^{\mathrm{T}}$ & 99.6 & Lake Chitu \\
\hline Isolate_9 & Enterobacter tabaci $\mathrm{YIM} \mathrm{Hb}-3^{\mathrm{T}}$ & 98.9 & Lake Chitu \\
\hline Isolate_10 & Enterobacter hormaechei subsp. hormaechei $10-17^{\mathrm{T}}$ & 98.0 & Yabello \\
\hline Isolate_11 (MW 722969) & Enterobacter bugandensis 247BMC & 99.2 & Wonji \\
\hline Isolate_12 & Enterobacter hormaechei subsp. hormaechei $10-17^{\mathrm{T}}$ & 99.9 & Lake Abijata \\
\hline Isolate_13 & Enterobacter tabaci YIM Hb-3 ${ }^{\mathrm{T}}$ & 98.2 & Lake Abijata \\
\hline Isolate_14 & Bacillus wiedmannii FSLW8-0169 $9^{\mathrm{T}}$ & 98.7 & Tulubolo \\
\hline Isolate_15 & Enterobacter tabaci YIM Hb-3 ${ }^{\mathrm{T}}$ & 98.9 & West Wellega \\
\hline Isolate_16 & Enterobacter tabaci YIM Hb-3 ${ }^{\mathrm{T}}$ & 99.0 & Yabello \\
\hline Isolate_17 & Enterobacter asburiae JCM $6051^{\mathrm{T}}$ & 97.2 & Yabello \\
\hline Isolate_18 & Citrobacter sedlakii $\mathrm{I}-25^{\mathrm{T}}$ & 99.2 & Tulubolo \\
\hline Isolate_19 & Enterobacter tabaci YIM Hb-3 $3^{\mathrm{T}}$ & 98.2 & Tulubolo \\
\hline Isolate_20 & Enterobacter tabaci YIM Hb-3 $3^{\mathrm{T}}$ & 98.8 & Yabello \\
\hline
\end{tabular}

$\%$ indicates similarity.

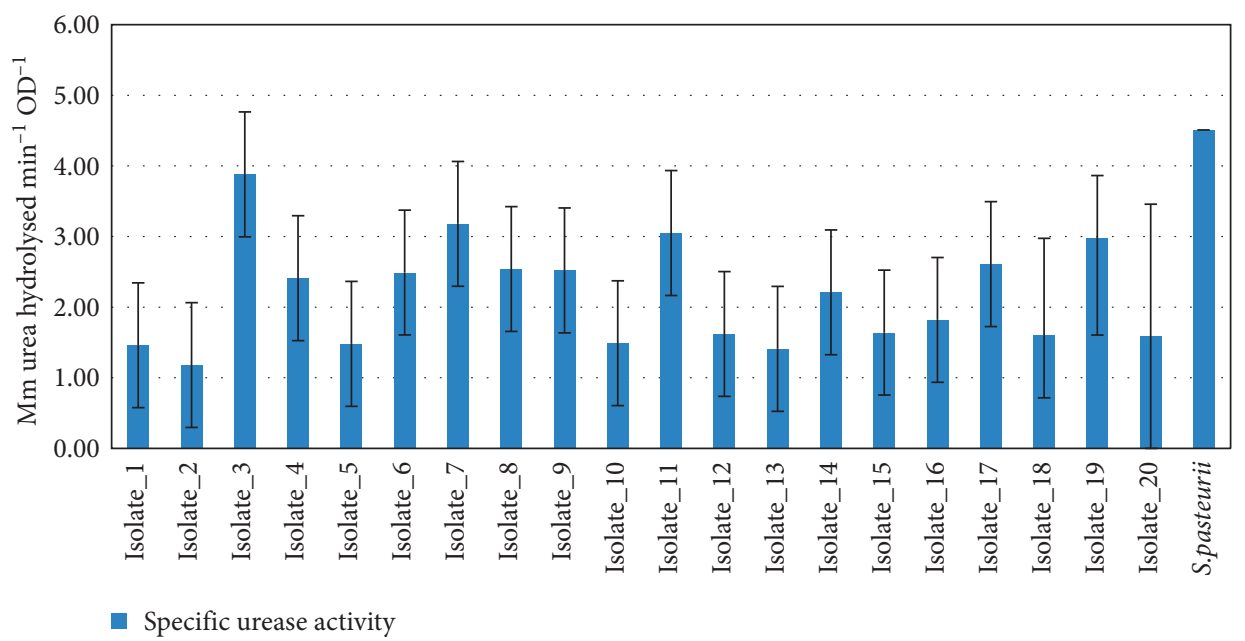

FIGURE 1: Specific urease activity.

$4^{\circ} \mathrm{C}-25^{\circ} \mathrm{C}$ and $45^{\circ} \mathrm{C}$. Isolate_ 3 was able to grow between $25^{\circ} \mathrm{C}$ and $40^{\circ} \mathrm{C}$ with optimum growth between $35^{\circ} \mathrm{C}$ and $40^{\circ} \mathrm{C}$. It showed (very) limited or no growth between $4^{\circ} \mathrm{C}-20^{\circ} \mathrm{C}$ and $45^{\circ} \mathrm{C}$ (Figure 5).

The study of $\mathrm{NaCl}$ concentration tolerance also revealed that Isolate_11 was able to grow in $\mathrm{NaCl}$ concentration range of $0.0-5.0 \%$, where it grew best (optimum growth) between 0.25 and $3.0 \%(\mathrm{w} / \mathrm{v})$ in $48 \mathrm{~h}$ of incubation; the highest rate of growth $(100 \%)$ was recorded at $0.25 \%$. During the study, it was observed that Isolate_11 was unable to grow at $\mathrm{NaCl}$ concentrations $\geq 10 \%$. Optimal growth was observed between 0.0 and $2.0 \%(\mathrm{w} / \mathrm{v}) \mathrm{NaCl}$ for Isolate_7 and between 0.0 and $0.5 \% \mathrm{NaCl}$ for Isolate_3 after $24 \mathrm{~h}$ of incubation. The highest rate of growth was recorded at $0.25 \% \mathrm{NaCl}$ for both strains and they showed zero growth at $\mathrm{NaCl}$ concentrations of $\geq 10 \%$ (Figure 6).
3.3. Exoenzyme Profiles of the Selected Strains. In addition to urease activity, the selected isolates showed activities for various exoenzymes (Table 2). Out of 25 tested exoenzymes, Isolate_11 showed activities for 14 exoenzymes; Isolate_7 showed for 13 exoenzymes; and Isolate_3 for 11 exoenzymes. All the three selected strains showed similar preferences towards phosphate-containing compounds (alkaline phosphatase, acid phosphatase, and naphtholAS-BI-phosphohydrolase), peptidase activities (leucine arylamidase and valine arylamidase), and nitrate reductase activity. They all assimilated $\mathrm{N}$-acetyl-glucosamine, D-maltose, potassium gluconate, and trisodium citrate. Isolate_3 and Isolate_7 showed a similar positive reaction for lipids (esterase and esterase lipase), while Isolate_11 and Isolate_7 showed similar preferences for trypsin and $\beta$-galactosidase. Isolate_11 showed unique preferences for 


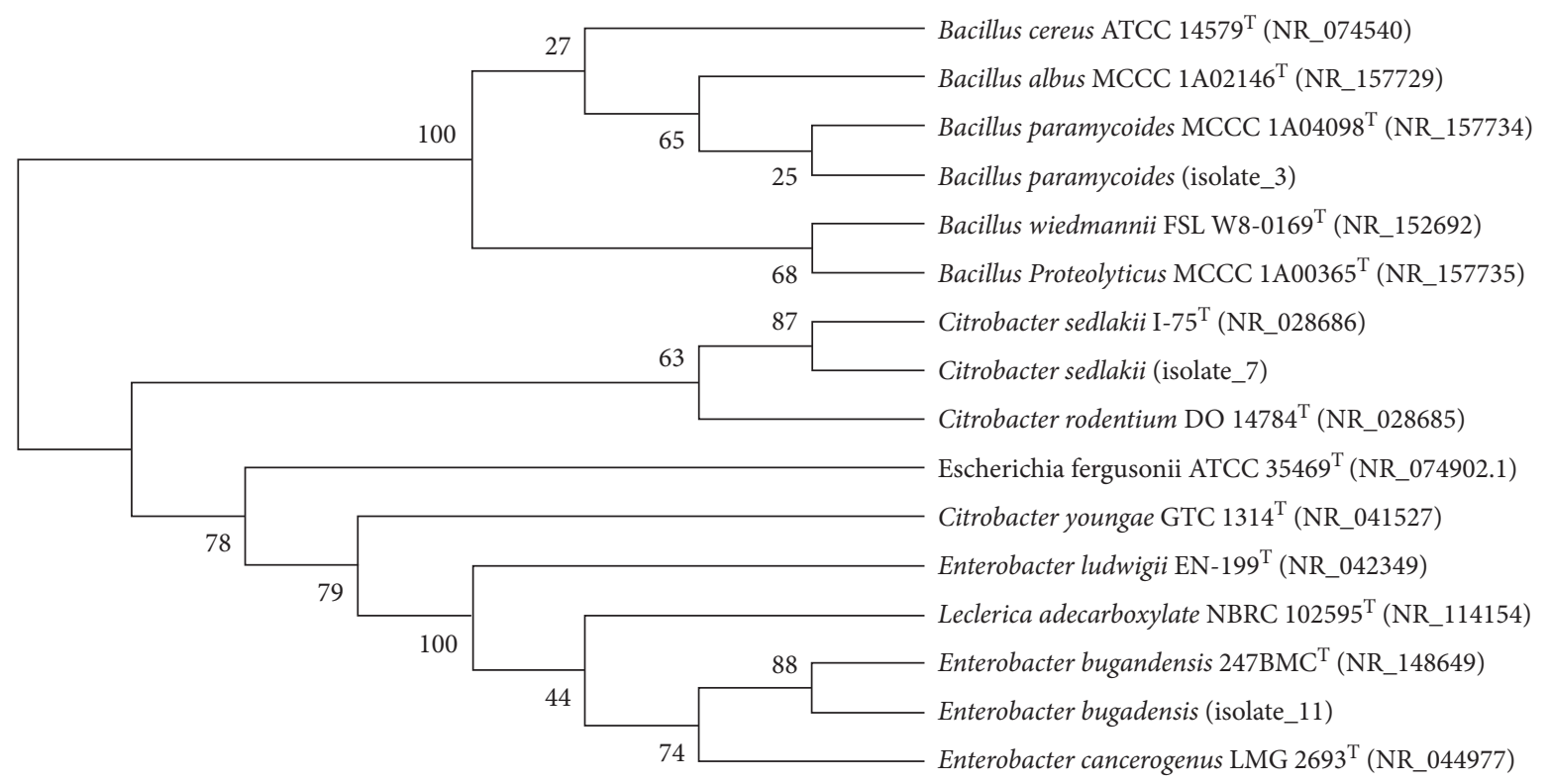

FIGURE 2: Molecular phylogenetic analysis by maximum likelihood method based on almost-full-length 16S rRNA gene sequences illustrating the phylogenetic position of Isolate_3, Isolate_7, and Isolate_11 and related taxa. The percentage of trees in which the associated taxa clustered together are shown next to the branches.

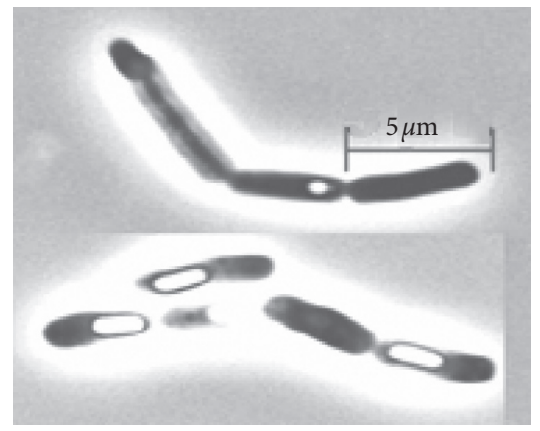

(a)

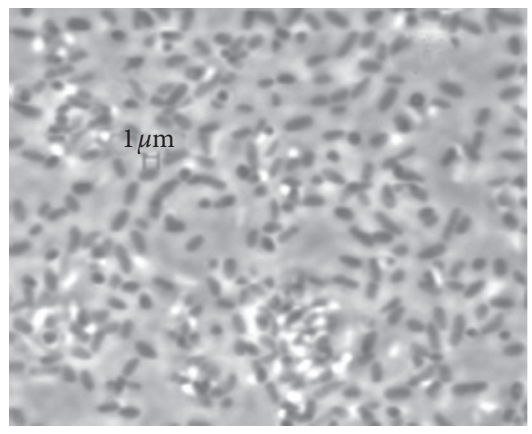

(b)

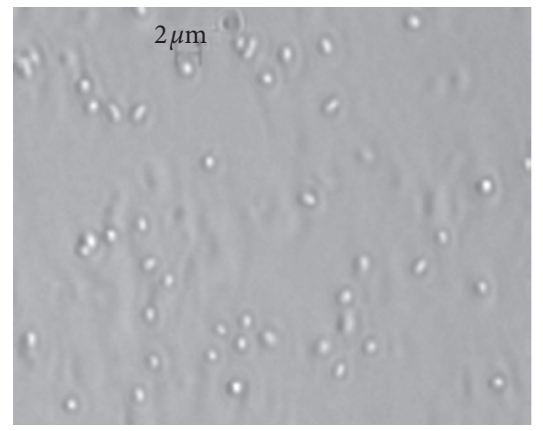

(c)

FIgURE 3: $(\mathrm{a}, \mathrm{b}, \mathrm{c})$ Phase-contrast photomicrographs of strains: Isolate_3, Isolate_7, and Isolate_11.

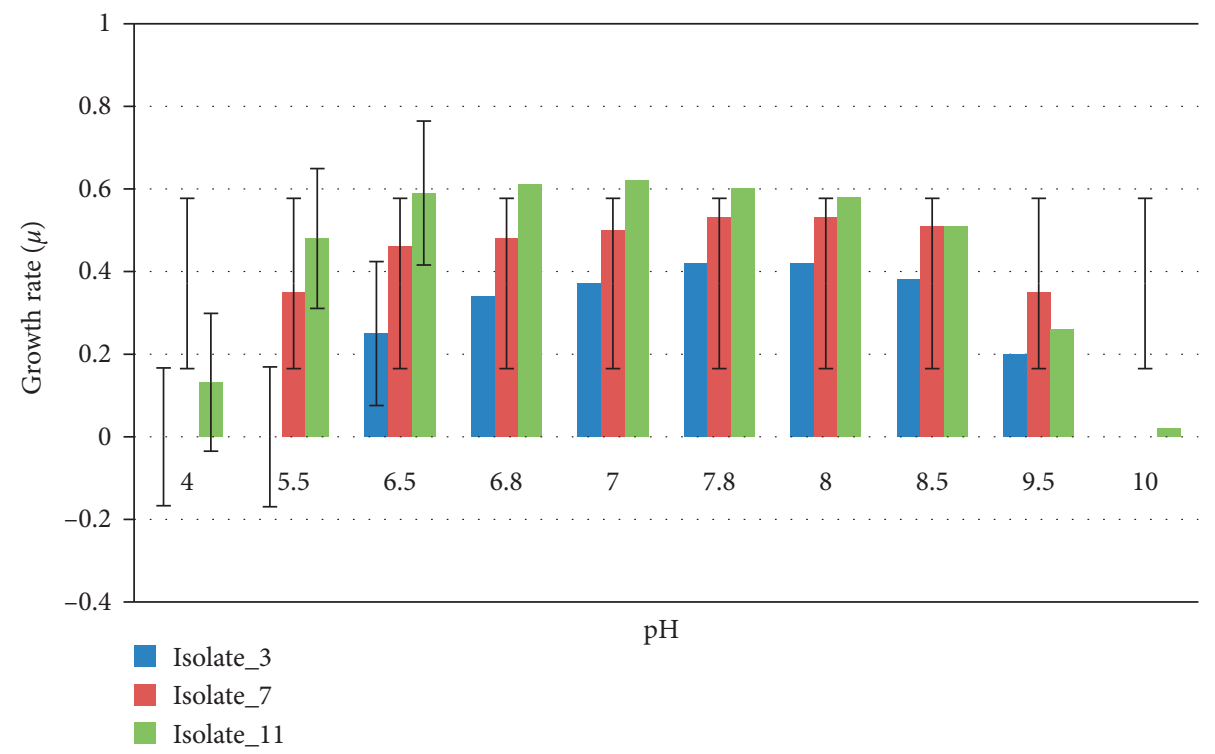

FIGURE 4: $\mathrm{pH}$ growth optimum and range analysis of the strains Isolate_11, Isolate_7, and Isolate_3, respectively. 


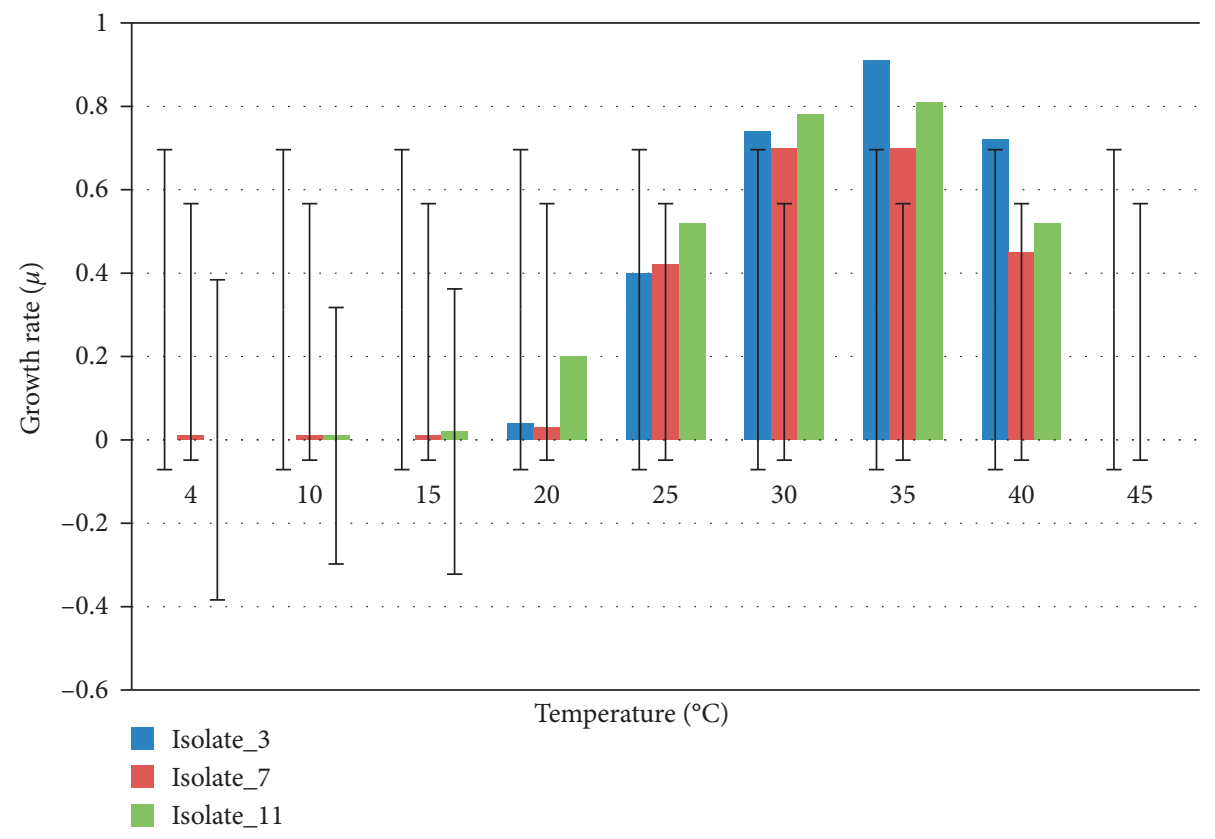

FIgURE 5: Temperature optimum and range analysis of strains of Isolates_11, Isolate_7, and Isolate_3, respectively.

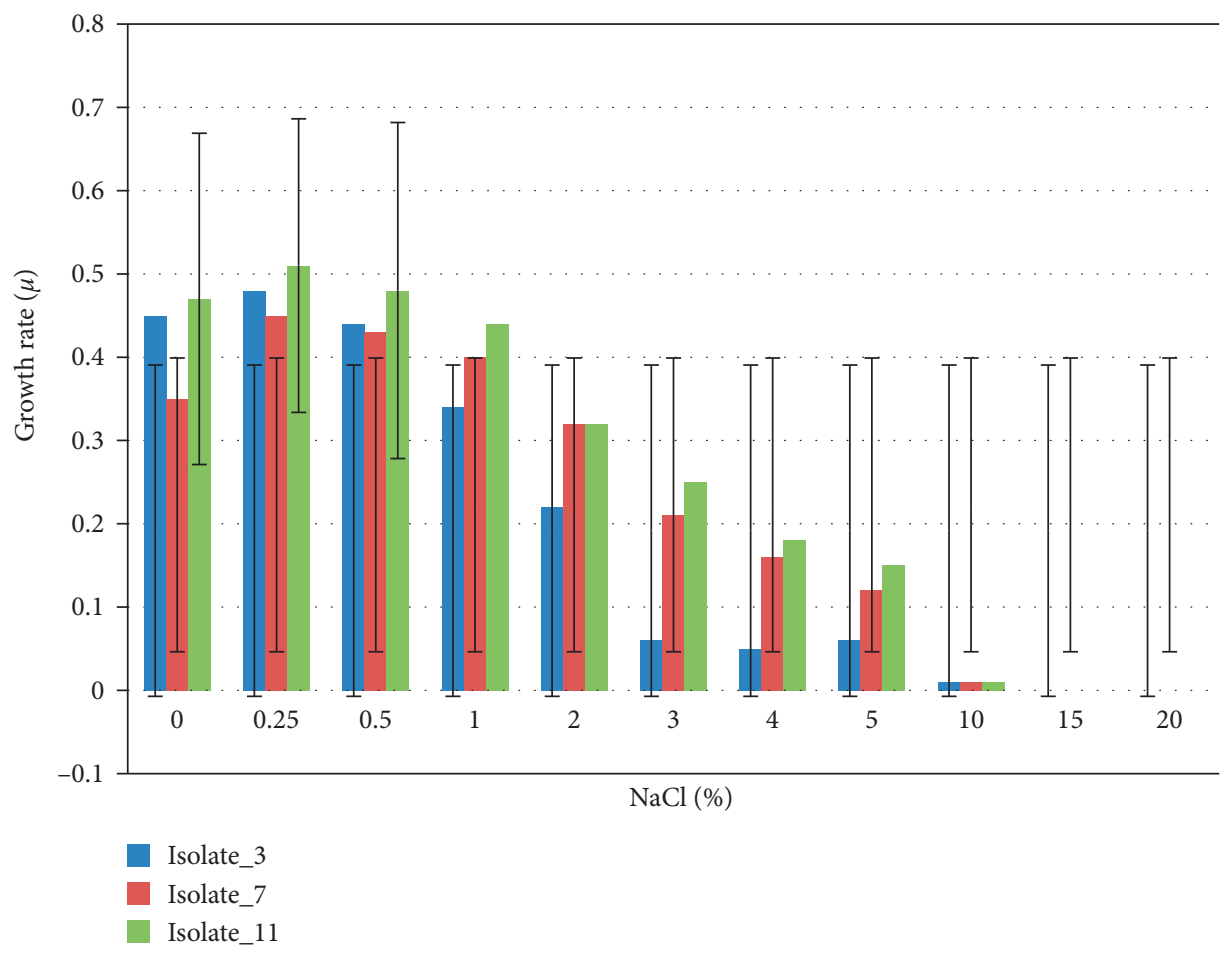

Figure 6: $\mathrm{NaCl}$ tolerance, optimum, and range analysis of the strains of Isolate_7, Isolate_11, and Isolate_3, respectively.

various sugars ( $\alpha$-glucosidase, $\beta$-glucosidase, and $\mathrm{N}$-acetyl$\beta$-glucosaminidase).

\section{Discussions}

This study was conducted with the aim of isolation and characterization of rapid urease-producing bacteria from Ethiopian soils. In the study, twenty urease-producing bacterial isolates were identified using a qualitative urease activity assay. Among these, three of them (Bacillus paramycoides, Citrobacter sedlakii, and Enterobacter bugandensis) expressed urease at high rates $(3.88,3.18$, and 3.05 of $\mathrm{mM}$ urea hydrolysed $\left.\mathrm{min}^{-1} \mathrm{OD}^{-1}\right)(p<0.05)$ as determined by a conductivity assay. Literature showed that urease was studied from several bacterial strains such as Bacillus [54], Citrobacter, Enterobacter, Pseudomonas, Serratia, and 
TABLE 2: Biochemical and exoenzyme profiles of the three selected strains.

\begin{tabular}{|c|c|c|c|}
\hline Characteristics & Isolate_3 & Isolate_7 & Isolate_11 \\
\hline Control & - & - & - \\
\hline \multicolumn{4}{|l|}{ API $20 \mathrm{NE}$} \\
\hline Nitrate reductase & + & + & + \\
\hline Indole formation & - & + & - \\
\hline Arginine dihydrolase & - & $\mathrm{W}$ & + \\
\hline Urease & + & + & + \\
\hline Protease & + & - & + \\
\hline L-Arabinose & - & + & + \\
\hline \multicolumn{4}{|l|}{ API ZYM } \\
\hline Alkaline phosphatase & + & + & + \\
\hline Esterase $(\mathrm{C} 4)$ & $\mathrm{W}$ & $\mathrm{W}$ & - \\
\hline Esterase lipase (C8) & $\mathrm{W}$ & $\mathrm{W}$ & - \\
\hline Lipase (C14) & - & - & - \\
\hline Leucine arylamidase & + & + & + \\
\hline Valine arylamidase & $\mathrm{W}$ & $\mathrm{W}$ & + \\
\hline Cystine arylamidase & - & - & - \\
\hline Trypsin & - & $\mathrm{W}$ & $\mathrm{W}$ \\
\hline$\alpha$-Chymotrypsin & + & - & - \\
\hline Acid phosphatase & + & + & + \\
\hline Naphtanol-AS- & & & \\
\hline BI_phosphohydrolase & W & W & W \\
\hline$\alpha$-Galactosidase & - & - & - \\
\hline$\beta$-Galactosidase & - & + & + \\
\hline$\beta$-Glucuronidase & - & - & - \\
\hline$\alpha$-Glucosidase & + & - & $\mathrm{W}$ \\
\hline$\beta$-Glucosidase & - & - & W \\
\hline N-Acetyl- $\beta$-glucosaminidase & - & - & $\mathrm{W}$ \\
\hline$\alpha$-Mannosidase & - & - & - \\
\hline$\alpha$-Fucosidase & - & - & - \\
\hline
\end{tabular}

“+" = positive; "W" = weakly positive; and "-" = negative.

Yersinia [55]. In our study, the identified strains exhibiting urease activity were identified as belonging to the genera Bacillus, Citrobacter, and Enterobacter.

Consistent with previous studies done on Bacillus paramycoides MCCC $1 \mathrm{~A} 04098^{\mathrm{T}}$, Citrobacter sedlakii $2596^{\mathrm{T}}$ and Enterobacter bugandensis EB- $261^{\mathrm{T}}$ [51, 52, 56], similar morphological and physiological characteristics were observed with Isolate_3, Isolate_7, and Isolate_11, respectively, and later confirmed by $16 \mathrm{~S}$ rRNA gene sequencing. However, morphological studies have revealed that Isolate_3 was a spore former with conspicuous spore and had a rough colony and cells having a length of $1.5-4.5 \mu \mathrm{m}$ after incubation at $35^{\circ} \mathrm{C}$ for $18 \mathrm{~h}$. This makes Isolate_3 different from the previously characterized novel strain of B. paramycoides MCCC $1 \mathrm{~A} 04098^{\mathrm{T}}$ which was reported as nonspore forming, with $1.8-2.2 \mu \mathrm{m}$ in length and with waxy colonies after incubation at $32^{\circ} \mathrm{C}$ for $48 \mathrm{~h}$ on $\mathrm{LB}$ medium [56]. Besides, unlike the nonureolytic strain of B. paramycoides MCCC $1 \mathrm{~A} 04098^{\mathrm{T}}$, Isolate_3 is a urease producer. These are important key characteristics that differentiate our strain from the previously identified related strain of $B$. paramycoides MCCC $1 \mathrm{~A} 04098^{\mathrm{T}}$. Therefore, it is significant to note that Isolate_ 3 showed unique morphological and physiological features. On this basis, the isolate described here probably represents a new member of the genus Bacillus.
In addition, the morphological and physiological studies of Isolate_11 showed different characters from the previously characterized nonureolytic E. bugandensis strain EB$247^{\mathrm{T}}$ [51], as Isolate_11 does not form a capsule but secretes urease and gelatinase enzymes and assimilates $\mathrm{D}$-arabinose following incubation for $18 \mathrm{~h}$ at $35^{\circ} \mathrm{C}$, while the former was incubated for $24 \mathrm{~h}$ at $37^{\circ} \mathrm{C}$ on MacConkey agar. The most prominent biochemical feature of Isolate_ 7 was its ability to assimilate aesculin ferric citrate, which agrees with the name of the genus (Citrobacter = citrate utilizing rods) [57]. Furthermore, similar biochemical and morphological features were also observed between Isolate_7 and clinical isolate Citrobacter sedlakii $2596^{\mathrm{T}}$ [52] with respect to urease activity, arginine hydrolase, and fermentation of arabinose, mannitol, and maltose. Jacob [57] also reported a similar positive reaction for urease, arginase, lipase, and $\beta$-glucosidase for halophilic Citrobacter strains isolated from the saline environment. But, the reported strain had filamentous and rough colonies unlike Isolate_7, which showed convex and circular colonies with an average size of $2.5 \mathrm{~mm}$. Brenner et al. [58] reported that Citrobacter sedlakii ATCC $51118^{\mathrm{T}}$ has similar positive results to Isolate_7 with respect to urease activity and arginine dihydrolase and is different in its negative reaction with aesculin substrate utilization.

Though the selected strains were isolated from mountainous agricultural land termite mound soil (Isolate_11) with a slightly neutral $\mathrm{pH}$ of 6.7 and rift valley grassland termite mound soil (Isolate_3 and Isolate_7) with slightly alkaline $\mathrm{pH}$, respectively, they tolerated a broader $\mathrm{pH}$ range as explained above and based on their optimum growth $\mathrm{pH}$ of 5.5-8.5 $(p<0.05)$, they are categorized as neutrophiles [59]. They were grown at moderate temperatures between $20^{\circ} \mathrm{C}$ and $40^{\circ} \mathrm{C}$ and with an optimum growth temperature in the range of $30-39^{\circ} \mathrm{C}$. Therefore, they are categorized as mesophilic bacteria [60]. The isolates showed a narrow tolerance range for temperature corresponding to their origin from Ethiopian soil.

As shown in Figure 5, all the three selected strains tolerated $\mathrm{NaCl}$ concentrations of up to $5 \%(\mathrm{w} / \mathrm{v})$, which exceeds the maximum $\mathrm{NaCl}$ tolerance of common soil bacteria. This increased $\mathrm{NaCl}$ tolerance constitutes an important differential characteristic of the selected species. It best explains the higher salinity in Ethiopian soils [61], which could be due to heavy fertilizer application, use of poor quality irrigation water, and inadequate drainage [64, $65,66]$. Nonhalophiles grow optimally at less than $2 \% \mathrm{NaCl}$; slight halophiles grow optimally at $2-5 \% \mathrm{NaCl}$; moderate halophiles grow optimally at $5-20 \% \mathrm{NaCl}$; and extreme halophiles grow optimally above $20-30 \% \mathrm{NaCl}$ [62]. This implies that the rapid urease-producing isolates in this study could be considered as nonhalophilic to slightly halophilic bacteria. Further studies of such halophilic bacteria could help to discover new enzymes to be applied in biocatalytic processes that are faster, more accurate, specific, and environmentally friendly [63]. These enzymes could keep high activity and stability in salty environments and could have potential application values in agriculture, engineering, and medicine. 


\section{Conclusions}

The results obtained from this research confirmed the presence of ureolytic bacteria in Ethiopian soil indicating their adaptation from the rift valley to mountainous ecosystems of the country. In the study, new strains of Bacillus, Citrobacter, and Enterobacter were isolated from Ethiopian soil and characterized based on their distinctive physiological and morphological characteristics. From the study, it was shown that the three isolates (Isolate_3, Isolate_7, and Isolate_11) had relatively more rapid rates of urea hydrolysis and were found to be nonhalophilic to slightly halophilic neutrophiles and aerobic mesophiles with a range of tolerance towards $\mathrm{pH}(4.0-10.0), \mathrm{NaCl}(0.25-5 \%)$, and temperature $\left(20-40^{\circ} \mathrm{C}\right)$. Further studies on the growth profiles of the isolates, calcite precipitation, soil biocementation, and scanning electron microscopy analysis were recommended for future studies.

\section{Data Availability}

The data are available upon request to the corresponding author.

\section{Conflicts of Interest}

The authors declare that there are no conflicts of interest regarding this paper.

\section{Acknowledgments}

The authors acknowledge Addis Ababa Science and Technology, Ethiopia, for providing laboratory facilities during soil sample collection, bacterial isolation, and culturing work. They also acknowledge Leibniz-Institute DSMZ-Deutsche Sammlung von Mikroorganismen und Zellkulturen, Braunschweig, Germany, for providing facility during molecular and physiological characterization of the isolates. This work was supported by Ministry of Science and Higher Education (Ethiopia), Ministry of Innovation and Technology (Ethiopia), and DAAD (Grant no. 57381332) 2018.

\section{References}

[1] L. Kigigha, D. Silas-Olu, and D. Finebone, "Characterization of ureolytic bacteria from nitrogenous waste dumps in port harcourt Nigeria," Continental Journal of Microbiology, vol. 6, no. 1, pp. 9-13, 2012.

[2] R. Guettes, W. Dott, and A. Eisentraeger, "Determination of urease activity in soils by carbon dioxide release for ecotoxicological evaluation of contaminated soils," Ecotoxicology, vol. 11, no. 5, pp. 357-364, 2002.

[3] A. Omoregie, N. Senian, P. Ye Li et al., "Ureolytic bacteria isolated from Sarawak limestone caves show high urease enzyme activity comparable to that of Sporosarcina pasteurii (DSM 33)," Malaysian Journal of Microbiology, vol. 12, no. 6, pp. 463-470, 2016.

[4] A. I. Omoregie, G. Khoshdelnezamiha, N. Senian, D. E. L. Ong, and P. M. Nissom, "Experimental optimisation of various cultural conditions on urease activity for isolated
Sporosarcina pasteurii strains and evaluation of their biocement potentials," Ecological Engineering, vol. 109, pp. 65-75, 2017.

[5] C. M. Collins and S. E. F. D'Orazio, "Bacterial ureases: structure, regulation of expression and role in pathogenesis," Molecular Microbiology, vol. 9, no. 5, pp. 907-913, 1993.

[6] H. L. T. Mobley and R. P. Hausinger, "Microbial ureases: significance, regulation, and molecular characterizationt," American Society for Microbiology, vol. 53, no. 1, pp. 85-108, 1989.

[7] D. C. Cullen, R. S. Sethi, and C. R. Lowe, "Multi-analyte miniature conductance biosensor," Analytica Chimica Acta, vol. 231, no. 1, pp. 33-40, 1990.

[8] P. M. Glibert, J. Harrison, C. Heil, and S. Seitzinger, "Escalating worldwide use of urea-a global change contributing to coastal eutrophication," Biogeochemistry, vol. 77, no. 3, pp. 441-463, 2006.

[9] A. Omoregie, D. Ong, and P. Nissom, "Assessing ureolytic bacteria with calcifying abilities isolated from limestone caves for biocalcification," Letters in Applied Microbiology, vol. 68, no. 2, pp. 173-181, 2019.

[10] V. Achal, A. Mukherjee, and M. S. Reddy, "Original research: biocalcification by Sporosarcina pasteuriiusing corn steep liquor as the nutrient source," Industrial Biotechnology, vol. 6, no. 3, pp. 170-174, 2010.

[11] J. T. DeJong, K. Soga, S. A. Banwart et al., "Soil engineering in vivo: harnessing natural biogeochemical systems for sustainable, multi-functional engineering solutions," Journal of The Royal Society Interface, vol. 8, no. 54, pp. 1-15, 2011.

[12] I. R. K. Phang, Y. S. Chan, K. S. Wong, and S. Y. Lau, "Isolation and characterization of urease-producing bacteria from tropical peat," Biocatalysis and Agricultural Biotechnology, vol. 13, pp. 168-175, 2018.

[13] O. A. Cuzman, S. Rescic, K. Richter, L. Wittig, and P. Tiano, "Sporosarcina pasteurii use in extreme alkaline conditions for recycling solid industrial wastes," Journal of Biotechnology, vol. 214, pp. 49-56, 2015.

[14] K. N. Paulson and L. T. Kurt, "Locus of urease activity in soil," Soil Science Society of America, vol. 33, pp. 897-901, 1969.

[15] S. Skujip, "Extracellular enzymes in soil," Critical Reviews in Microbiology, vol. 4, no. 4, pp. 383-421, 1976.

[16] L. Lindenbaum, Soil Stabilization System, United States Patent Application Publication, Alexandria, VA, USA, 2008.

[17] J. Tingle and R. Santoni, "Stabilization of clay soils with nontraditional additives," Transportation Research Record, vol. 1819, no. 1, 2003.

[18] D. E. Scholen, "Stabilizer mechanisms in nonstandard stabilizers," in Proceedings of the Sixth International Conference on Low-Volume Roads, II (TRB), pp. 252-260, National Research Council, May 1995, Washington, DC, USA.

[19] S. J. Tingle, J. K. Newman, S. L. Larson, C. A. Weiss, and J. F. Rushing, "Stabilization mechanisms ofnontraditional additives," Journal of the Transportation Research Board, vol. 1989, no. 2, pp. 59-67, 2007.

[20] A. B. Lloyd and M. J. Sheaffe, "Urease activity in soils," Plant and Soil, vol. 39, pp. 71-80, 1973.

[21] A. I. Omoregie, N. Senian, P. Ye Li et al., "Screening for urease-producing bacteria from limestone caves of sarawak," Borneo Journal of Resource Science and Technology, vol. 6, no. 1, pp. 37-45, 2016.

[22] V. Varalakshmi and A. Devi, "Isolation and characterization of urease utilizing bacteria to produce biocement," IOSR Journal of Environmental Science, Toxicology and Food Technology, vol. 8, no. 4, pp. 52-57, 2014. 
[23] G. Gebreyohannes, F. Moges, S. Sahile, and N. Raja, "Isolation and characterization of potential antibiotic producing actinomycetes from water and sediments of Lake Tana, Ethiopia," Asian Pacific Journal of Tropical Biomedicine, vol. 3, no. 6, pp. 426-435, 2013.

[24] M. Kibret, J. F. Guerrero-Garzón, E. Urban et al., "Streptomyces spp. from Ethiopia producing antimicrobial compounds: characterization via bioassays, genome analyses, and mass spectrometry," Frontiers in Microbiology, vol. 9, p. 1270, 2018.

[25] Eshetu Mekonnen, Ameha Kebede, Tekle Tafesse, and Mesfin Tafesse, "Investigation of carbon substrate utilization patterns of three ureolytic bacteria," Biocatalysis and Agricultural Biotechnology, vol. 22, Article ID 101429, 2019.

[26] V. A. Lancaster and S. Keller-McNulty, "A review of composite sampling methods," Journal of the American Statistical Association, vol. 93, pp. 1216-1230, 1998.

[27] R. Sadati, A. Barghi, and M. Jafarpour, "Isolation and identification of novel lipase-producing microbacterium spp. from coastal soils of the Caspian Sea (North of Iran)," World Applied Sciences Journal, vol. 23, no. 1, pp. 65-69, 2013.

[28] T. T. Fida, S. Palamuru, and G. Pandey, "Aerobic biodegradation of 2,4-Dinitroanisole by nocardioides sp. strain JS1661," Applied and Environmental Microbiology, vol. 80, no. 24, pp. 7725-7731, 2014.

[29] I. A. Hammad, F. N. Talkhan, and A. E. Zoheir, "Urease activity and induction of calcium carbonate precipitation by Sporosarcina pasteurii NCIMB 8841," Journal of Applied Sciences Research, vol. 9, no. 3, pp. 1525-1533, 2013.

[30] M. P. Harkes, L. A. van Paassen, J. L. Booster, V. S. Whiffin, and M. C. M. van Loosdrecht, "Fixation and distribution of bacterial activity in sand to induce carbonate precipitation for ground reinforcement," Ecological Engineering, vol. 36, no. 2, pp. 112-117, 2010.

[31] V. S. Whiffin, Microbial $\mathrm{CaCO}_{3}$ Precipitation for the Production of Biocement, Murdoch University Western Australia, Perth, Australia, 2004.

[32] R. Moyes, J. Reynolds, and D. Breakwell, "Differential staining of bacteria: gram stain," Current Protocols in microbiologyAppendix, vol. 3, no. 1, 2009.

[33] S. Vieira, M. Luckner, G. Wanner, and J. Overmann, "Luteitalea pratensis gen . nov., sp. nov. a new member of subdivision 6 acidobacteria isolated from temperate grassland soil," International Journal of Systematic and Evolutionary Microbiology, vol. 67, pp. 1408-1414, 2017.

[34] K. R. Arora, Soil Mechanics and Foundation Engineering, Springer, Berlin, Germany, 2019.

[35] T. Hall, "BioEdit: a user-friendly biological sequence alignment editor and analysis program for windows 95/98/NT," Nucleic Acids Symposium Series, vol. 41, no. 41, pp. 95-98, 1999.

[36] A. Naomi, S. Andre, and R. O. Cavalcanti, "Using NCBI BLAST," in Current Protocals., Essential Laboratory Techniques, 14, pp. 11.1.1-11.1.34, Wiley, Hoboken, NJ, USA, 2017.

[37] K. J. Huber, P. K. Wust, M. Rohde, A. Jorg Overmann, and B. U. Foesel, "Aridibacter famidurans gen. nov., sp. nov. and Aridibacter kavangonensis sp. nov., two novel members of subdivision 4 of the Acidobacteria isolated from semiarid savannah soil," International Journal of Systematic and Evolutionary Microbiology, vol. 64, pp. 1866-1875, 2014.

[38] M. Uyttebroek, S. Vermeir, P. Wattiau, A. Ryngaert, and D. Springael, "Characterization of cultures enriched from acidic polycyclic aromatic hydrocarbon-contaminated soil for growth on pyrene at low pH," Applied and Environmental Microbiology, vol. 73, no. 10, pp. 3159-3164, 2007.

[39] J. Pascual, B. U. Foesel, A. Geppert, K. J. Huber, and J. Overmann, "Flaviaesturariibacter luteus sp. nov., isolated from an agricultural floodplain soil, and emended description of the genus flaviaesturariibacter," International Journal of Systematic and Evolutionary Microbiology, vol. 67, no. 6, pp. 1727-1734, 2017.

[40] S. M. Tiquia, J. H. C. Wan, and N. F. Y. Tam, "Extracellular enzyme profiles during co-composting of poultry manure and yard trimmings," Process Biochemistry, vol. 36, no. 8-9, pp. 813-820, 2001.

[41] M. W. Humble, A. King, and I. Phillips, "API ZYM: a simple rapid system for the detection of bacterial enzymes," Journal of Clinical Pathology, vol. 30, no. 3, pp. 275-277, 1977.

[42] S. Bascomb and M. Manafi, "Use of enzyme tests in characterization and identification of aerobic and facultatively anaerobic gram-positive cocci," Clinical Microbiology Reviews, vol. 11, no. 2, pp. 318-340, 1998.

[43] K. Tamura, G. Stecher, D. Peterso, A. Filipski, and S. Kumar, "Mega 10: molecular evolutionary genetics analysis version 6.0," Molecular Biology and Evolution, vol. 30, no. 12, pp. 2725-2729, 2013.

[44] N. Saitou and M. Nei, "The neighbor-joining method: a new method for reconstructing phylogenetic trees," Molecular Biology and Evolution, vol. 4, no. 4, pp. 406-425, 1987.

[45] D. S. Katz, "The streak plate protocol," American Society for Microbiology, vol. 4, 1954.

[46] J. M. Janda and S. L. Abbott, "16S rRNA gene sequencing for bacterial identification in the diagnostic laboratory: pluses, perils, and pitfalls," Journal of Clinical Microbiology, vol. 45, no. 9, pp. 2761-2764, 2007.

[47] J. Ye, S. McGinnis, and T. L. Madden, "BLAST: improvements for better sequence analysis," Nucleic Acids Research, vol. 34, no. Web Server issue, pp. W6-W9, 2006.

[48] L. G. Wayne, D. J. Brenner, R. R. Colwell, P. A. D. Grimont, M. I. Krichevsky, and H. G. Truper, "Report of the ad hoc committee on reconciliation of approaches to bacterial systematics," International Journal of Systematic Bacteriology, vol. 37, no. 4, pp. 463-464, 1987.

[49] E. Stackebrandt and J. Ebers, "Taxonomic parameters revisited: tarnished gold standards," Microbiol Today, vol. 33, no. 4, pp. 152-155, 2006.

[50] R. P. Tittsler and L. A. Sandholzer, "The use of semi-solid agar for the detection of bacterial motility," Journal of Bacteriology, vol. 31, no. 6, pp. 575-580, 1936.

[51] S. Doijad, C. Imirzalioglu, Y. Yao et al., "Enterobacter bugandensis sp. nov., isolated from neonatal blood," International Journal of Systematic and Evolutionary Microbiology, vol. 66, no. 2, pp. 968-974, 2016.

[52] J. Dyer, K. C. Hayani, and W. M. Janda, P. C. Schreckenberger, Citrobacter sedlakii meningitis and brain abscess in a premature infant," Journal of Clinical Microbiology, vol. 35, no. 10, pp. 2686-2688, 1997.

[53] D. A. Dubnau, The Molecular Biology of the Bacilli, Elsevier, Amsterdam, Netherlands, 1985.

[54] J. T. Dejong, M. B. Fritzges, and K. Nüsslein, "Microbially induced cementation to control sand response to undrained shear," Journal of Geotechnical and Geoenvironmental Engineering, vol. 132, no. 11, pp. 1381-1392, 2006.

[55] H. Alizadeh, D. Kandula, J. Hampton, A. Stewart, D. Leung, and Y. Edwards, "Screening and identification of urease producing microorganisms from New Zealand pasture soils," 
in Bio Protection, pp. 78-85, Lincoln University, Lincoln, UK, 2014.

[56] Y. Liu, J. Du, Q. Lai et al., "Proposal of nine novel species of the Bacillus cereus group," International Journal of Systematic Evolutionary Microbiology, vol. 67, pp. 2499-2508, 2017.

[57] H. Jacob and F. I. Irshaid, "Biochemical and molecular taxonomy of a mild halophilic strain of Citrobacter isolated from hypersaline environment," Research Journal of Microbiology, vol. 7, no. 4, pp. 219-226, 2012.

[58] D. J. Brenner, P. A. Grimont, A. G. Steigerwal, E. Ageron, G. R. Fanning, and C. F. Riddle, "Classification of citrobacteria by DNA hybridization: designation of Citrobacter famzeri sp. nov., Citrobacter youngae sp. nov., Citrobacter braakii sp. nov., Citrobacter werkmanii sp. nov., Citrobacter sedlakii sp. nov., and three unnamed Citrobacter genomospecies," International Journal of Systematic Bacteriology, vol. 43, no. 4, pp. 645-658, 1993.

[59] R. Sánchez Clemente, M. Isabel Igeño, G. Población et al., "Study of $\mathrm{pH}$ changes in media during bacterial growth of several environmental strains," Proceedings, vol. 2, p. 1297, 2018.

[60] C. Schiraldi and M. Rosa, Mesophilic Organisms. Encyclopedia of Membranes, Springer, Berlin, Germany, 2014.

[61] M. Asmamaw, A. Haile, and G. Abera, "Characterization and classification of salt affected soils and irrigation water in Tendaho sugarcane production farm, North-Eastern Rift valley of Ethiopia," African Journal of Agricultural Research, vol. 13, no. 9, pp. 403-411, 2018.

[62] I. G. Proca, F. Matei, C. Filofteia, D. $\square$ ă, and $\square$. Jurcoane, "Salt tolerance of bacterial strains isolated from hypersaline water located in lopatari, Romania," Scientific Bulletin. Series F. Biotechnologies, vol. 21, pp. 229-232, 2017.

[63] B. van den Burg, "Extremophiles as a source for novel enzymes," Current Opinion in Microbiology, vol. 6, no. 3, pp. 213-218, 2003. 